\title{
INFLUENCE OF SELECTED MACROECONOMIC INDICATORS ON EMPLOYEE MOTIVATION
}

\section{Miloš Hitka1, Jozef Ďurian², Silvia Lorincová3 ${ }^{3}$ Bianka Dúbravská4}

1 Technical University in Zvolen, Faculty of Wood Sciences and Technology, Department of Business Economics, Slovakia, ORCID: 0000-0002-6567-7333, hitka@tuzvo.sk;

2 Matej Bel University, Faculty of Economics, Department of Corporate Economics and Management, Slovakia, ORCID: 0000-003-0617-2666, jozef.durian@umb.sk;

3 Technical University in Zvolen, Faculty of Wood Sciences and Technology, Department of Business Economics, Slovakia, ORCID: 0000-0002-5763-5002, lorincova@tuzvo.sk;

4 Technical University in Zvolen, Faculty of Forestry, Department of Economics and Management of Forestry, Slovakia, ORCID: 0000-0002-6059-4539, biankavaz17@gmail.com.

\begin{abstract}
Motivation is considered one of the most important prerequisites for the success and effectiveness of the resulting performances. Usually, we meet only with a perspective of employee motivation from inside the company. However, the external environment, i.e. macro-environment, also influences the motivation of employees. We decided to focus on exploring how macroeconomic indicators evolution affects employee motivation. By means of the research conducted in Slovakia during the period from 2008 to 2019 on a sample of more than 30,000 respondents, we define the dependence of selected macroeconomic indicators and employee motivation. The research focuses on the analysis of average annual wage and household debt influence on the most important employees' motivational factors. Based on our findings, we can state that macroeconomic indicators affect the importance of motivational factors in Slovakia. Especially, the average annual wage strongly influences the six motivational factors (communication at the workplace, duties and type of work, working hours, working environment, superior approach, psychological burden). The results of the research also show that the seven motivational factors (atmosphere at the workplace, good team, communication at the workplace, working hours, working environment, superior approach, psychological burden) strongly depend on the macroeconomic indicator of household debt. Therefore, when creating incentive programs, business managers in Slovakia should take into account not only the effects of the company's microenvironment on motivation but also the effects of the macro-environment and thus macroeconomic changes in the state. The role of a manager is to keep balance between external environment influence on employee motivation and internal actions. The paper presents inspiring ideas in a field of employee motivation and the influence of external environment on motivation.
\end{abstract}

Keywords: Employee motivation, macroeconomic indicators, average annual wage, household debt.

JEL Classification: E71, M54.

APA Style Citation: Hitka, M., Ďurian, J., Lorincová, S., \& Dúbravská, B. (2021). Influence of Selected Macroeconomic Indicators on Employee Motivation. E\&M Economics and Management, 24(3), 4-22. https://doi.org/10.15240/tul/001/2021-03-001

\section{Introduction}

In recent years, the importance of human resource management in companies has been growing unstoppably. It is related to the growth of modern technologies, the education of the population, dynamic movements in the market of goods and labour, the democratisation of society, etc. However, in the face of growing pressure, 
the complexity of change, and the competition they face on a daily basis, most executives have to cope with the growing conflict and divide between management and leadership requirements of organisations. Managers work under a lot of pressure and stress, so they do not have the time and sometimes the desire to be a leader, and conversely, leaders do not manage to be managers. Combining the two functions is extremely difficult. Because every company works first and foremost with people, there is always a large number of tasks that the company must successfully solve in order to exist. Since human resources are of strategic importance to everyone today, they are a prerequisite for the existence of the company and its further development. The management experience of top companies proves that what distinguishes them from average and below average is not commonly used technology or formal organisational and management procedures, but above all the ability to use people's creative potential and engage them in integrated efforts for business goals and at the same time personal expectations and attitudes arising from the needs of their employees. The employee's attitudes and behaviour are determined on the one hand by his views and upbringing, on the other hand, by the experience from the previous period, which shapes his future expectations. The conditions of his work and the expectations of the company are constantly confronted with these ideas and can lead to corrections of behaviour in a positive but also in a negative sense. In addition to internal factors that can be influenced by the company, there are also factors of the external environment that the company cannot influence. These are various social, political, technological and economic changes. The paper enriches the current level of knowledge of work motivation issues by macroeconomic factors influence analysis. The aim of the work is to define the dependence of selected macroeconomic indicators and motivation of employees of Slovak companies. The subject of the research is financial, macroeconomic indicators such as the average annual wage and household debt. We consider salary to be the most important financial motivating factor, which affects not only the level of motivation but also the involvement of employees, their performance and quality of work. From time immemorial, money has been a universal tool that can serve a variety of needs. It can be about the needs of existential character, status character, the character of pleasure of surplus, etc. If the salary is adequate, an employee is able to satisfy existential and material needs, which is considered to be the strongest motive for human behaviour.

\section{Theoretical Background}

The business environment of the 21st century is characterised by an immense pace of various changes (Hajdúchová \& Hlaváčková, 2014; Bajzikova et al., 2017; Kalina, 2020). Dynamic changes at product markets are influencing customer's expectations and demands (Ližbetinová, 2017; Halaj et al., 2018). Companies are under a big pressure (Sedliacikova et al., 2015). According to Jelačić et al. (2015), Strakova et al. (2016), Weberová and Ližbetinová (2016), Štarchoň et al. (2017), Bravena and Stara (2018), Koval'ová et al. (2018), Karpichev et al. (2019), Kohnová et al. (2019), Stacho et al. (2019), Paluš et al. (2019), Stachová et al. (2020), and Neykov et al. (2021), the existence of a company is mostly dependent on the use of different business activities, that are able to maintain the desired market share of the company and at the same time to achieve the planned company revenue. In this context, employee motivation is considered to be the company's primary competitive advantage (Zaborova \& Markova, 2018; Bohorquez et al., 2020; Pogodina et al., 2020). There are several definitions of motivation that differ in the way they are expressed or formulated, but which are mostly similar in content. The designation motivation is used for virtually all the circumstances, facts or situations that people experience, perceive as important, and to which the question of why, for what reason, on what incentives and decision-making. In the business environment, it is essentially a process that fills in energy, directs and promotes employee behaviour and performance (Luthans, 1999). Concerning work motivation, Klopotan et al. (2018) state, that motivation has an impact on employees. It helps them reach the pinnacle of their abilities. Motivated employees are subsequently innovative, believe in themselves, which is beneficial to the success of the company (Yang \& Jiang, 2010; Stacho \& Stasiak-Betlejewska, 2014). According to research of Bowen and 
Radhakrishna (1991), Kropivšek et al. (2011), Rajhans (2012), Stacho et al. (2017), and Bohorquez et al. (2020), highly motivated employees are a valuable asset for businesses, because they bring value, new ideas and increase efficiency, quality and productivity of work. Motivated employees are able to create positive attitudes. They are more likely to accomplish better work performance (Crewson, 1997; Afsar \& Umrani, 2020). They show a higher level of commitment to the enterprise. For this reason, the strength of motivation should never be underestimated, since it is an essential element that enables the enterprise to survive (Smith, 1994; Stachová et al., 2018; Anguelov et al., 2020; Olafsen \& Bentzen, 2020).

Previous research (Joniaková \& Blštáková, 2015; Antov et al., 2017; Stalmasekova et al., 2017; Bellé \& Cantarelli, 2018; Mahmoud et al., 2020; Ritala et al., 2020) point to a wide range of factors that influence employee motivation. According to the research of Achim et al. (2013), Srivastava (2014), Barreto et al. (2018), Renard and Snelgar (2018), and Ju (2020), money is the primary factor of motivation that motivates employees to efficiency. This factor has the ability to maintain and motivate individuals to do better, because an individual can use the money to meet their needs. Also, the research of Dahake (2018) confirms the fact, that financial remuneration is a key motivating factor, as it has a significant impact on the building of care and the commitment of employees to the company. Studies by Elton Mayo have found that employees are not motivated solely by money. According to Herzberg (1968), some employees are motivated by factors such as company policy and administration, supervision, salary, interpersonal relationships, and working conditions; some people may be motivated by factors relating to the content of their work and are therefore motivators themselves. Amabile and Kramer (2010) discovered that the most important factor is career growth. The results of Houston (2000) research show that meaningful work was the most important motivation for both public and private sector employees. Çinar et al. (2011) claim that employees are usually motivated by a combination of different factors. The staff of western economies are motivated primarily by salary and prestige, often complemented by meaning, creation, challenge, ownership, identity, etc (Damij et al.,
2015). According to Chatzopoulou et al. (2015), employees are motivated by work primarily and then by working conditions. The results of the research of Fakhrutdinova et al. (2013) show that employees are motivated by factors such as bonuses, career growth, or obtaining the right to purchase shares of the company at a discounted price. Myint et al. (2016) claim that the 'supervisors', 'co-workers', 'compensation', and 'job contents', are factors that lead to job satisfaction.

Extensive attention is paid to motivation as one of the most important prerequisites for the success and effectiveness of the resulting performances. Previous research (Faletar et al., 2016) examines employee motivation in a wood processing company before and after restructuring. llea et al. (2020) performed similar research in hospitals. Houston (2000) examined the motivations of both public and private sector employees. Dick (2019) and Rožman et al. (2020) examine motivation in terms of the age of employees. However, when looking at the motivation of employees, we quite often only encounter a view from inside the company. There is no research dedicated to analysis of relationship between employee motivation and macroeconomic factors. This is the reason, why we are opening new knowledge 'niche' in the field of motivation. The external environment, i.e. the macro environment, affects employee motivation, even as internal company factors do. These are all external incentives that affect businesses. Because research conducted by Závadský (2015) shows that the motivation of employees also depends on the economic crisis, which affects the enterprise from the external environment and at the same time according to Jurečka (2013) the economic crisis is reflected in the values of macroeconomic indicators.

\section{Research Methodology}

Research on motivation was carried out in Slovakia. It took place between 2008 and 2019. Data were gathered by electronically distributed questionnaires. The questionnaires were submitted to randomly selected employees working in Slovakia in order to ensure variability and randomness of respondent selection necessary for relevant data acquisition. All part of Slovakia were covered by the research sampling unit. A total of 31,937 respondents participated in the composition, according to Tab. 1. 


\section{Tab. 1: Number of respondents in the years of research}

\begin{tabular}{c|c|c|c|c|c|c|c|c|c|c|c|c} 
Year & $\mathbf{2 0 0 8}$ & $\mathbf{2 0 0 9}$ & $\mathbf{2 0 1 0}$ & $\mathbf{2 0 1 1}$ & $\mathbf{2 0 1 2}$ & $\mathbf{2 0 1 3}$ & $\mathbf{2 0 1 4}$ & $\mathbf{2 0 1 5}$ & $\mathbf{2 0 1 6}$ & $\mathbf{2 0 1 7}$ & $\mathbf{2 0 1 8}$ & $\mathbf{2 0 1 9}$ \\
\hline $\begin{array}{l}\text { Number of } \\
\text { respondents }\end{array}$ & 339 & 780 & 1,822 & 686 & 1,054 & 7,009 & 4,314 & 4,099 & 4,470 & 3,720 & 2,104 & 1,540 \\
\hline
\end{tabular}

Source: own

A questionnaire was developed to find out the level of motivation. Questionnaire consisted of 30 closed questions. We gathered information on the characteristics of the working environment, working conditions, the evaluation and remuneration system, staffing of the undertaking itself, the social welfare system and the employee benefits, as well as information on the value orientation of the employee, the relationship to work, to colleagues and the undertaking as a whole (Hitka, 2009). Respondents assigned one of five degrees of importance according to the Likert scale of importance to each motivation factor (Zumbo et al., 2007). The symmetrical scaler range is from 1 to 5 (value 5 = very important, 4 = important, 3 = neutral, 2 = low important, $1=$ not important). We evaluated the level of importance by the arithmetic mean and other mathematical-statistical methods. In examining the influence of selected macroeconomic indicators on the level of employee motivation, a paired regression was used. A regression model (regression line) has a form of linear function (Pacáková, 2009):

$$
f(a, b)=\sum\left(y_{i}-a-b x_{i}\right)^{2}
$$

The parameters of the formula of straight line $a, b$ were determined based on the following:

$$
\begin{gathered}
a=\frac{\sum x_{i}^{2} \sum y_{i}-\sum x_{i} \sum x_{i} y_{i}}{n \sum x_{i}^{2}-\left(\sum x_{i}\right)^{2}} \\
b=\frac{n \sum x_{i} y_{i}-\sum x_{i} \sum y_{i}}{n \sum x_{i}^{2}-\left(\sum x_{i}\right)^{2}}
\end{gathered}
$$

The calculated parameters $a, b$ have been entered in the general shape of the straight-line formula:

$$
\bar{y}=a+b x i
$$

The degree of dependence between variables was characterised by rates of tightness of statistical dependence in the function (Pacáková, 2009):

$$
\begin{aligned}
& r=\frac{\operatorname{cov}(X, Y)}{S_{x} * S_{y}}=\cdots= \\
& =\frac{\sum x_{i} y_{i}-n \bar{x} \bar{y}}{\sqrt{\sum x_{i}^{2}-n \bar{x}^{2} * \sqrt{\sum y_{i}^{2}-n \bar{y}^{2}}}}
\end{aligned}
$$

The correlation coefficient $(r)$ achieves the values from an interval of $\{-1 ; 1\}$. They determine the degree of linear dependence between the variables $\mathrm{X}$ and $\mathrm{Y}$. The closer the value of the correlation coefficient is to 1 , the stronger is the linear dependence and conversely (Pacáková, 2009):

$\begin{aligned}|r| & <0.3 & & \text { low dependency } \\ 0.3 \leq|r| & <0.5 & & \text { mild dependency } \\ 0.5 \leq|r| & <0.7 & & \text { significant dependency } \\ 0.7 \leq|r| & <0.9 & & \text { high dependency } \\ 0.9 \leq|r| & <|r| & & \text { very high dependency }\end{aligned}$

The coefficient of determination $\left(r^{2}\right)$ is the proportion of the variance in the dependent variable that is predictable from the independent variable. Theoretical values were estimated according the regression line. We stated the levels of correlation tightness by the coefficient of determination as follow (Pacáková, 2009):
$r^{2}<0.3$
low tightness
$0.3 \leq r^{2}<0.5$
mild tightness
$0.5 \leq r^{2}<0.7$
significant tightness
$0.7 \leq r^{2}<0.9$
high tightness
$0.9 \leq r^{2}<|r|$
very high tightness 


\section{Economics}

\section{Tab. 2: Development of macroeconomic indicators in Slovakia}

\begin{tabular}{l|c|c|c|c|c|c|c|c|c|c|c|c}
\multicolumn{2}{c|}{ Indicator } & $\mathbf{2 0 0 7}$ & $\mathbf{2 0 0 8}$ & $\mathbf{2 0 0 9}$ & $\mathbf{2 0 1 0}$ & $\mathbf{2 0 1 1}$ & $\mathbf{2 0 1 2}$ & $\mathbf{2 0 1 3}$ & $\mathbf{2 0 1 4}$ & $\mathbf{2 0 1 5}$ & $\mathbf{2 0 1 6}$ & $\mathbf{2 0 1 7}$ \\
\hline $\begin{array}{l}\text { Average annual wage } \\
\text { (EUR) }\end{array}$ & 10,980 & 11,089 & 11,462 & 11,967 & 11,861 & 11,730 & 11,819 & 12,048 & 12,494 & 12,915 & 13,201 \\
\hline $\begin{array}{l}\text { Household } \\
\text { debt } \\
(\% \text { GDP) }\end{array}$ & SR & 21.91 & 24.40 & 27.31 & 27.81 & 29.16 & 30.90 & 32.92 & 35.23 & 37.49 & 40.43 & 42.64 \\
\cline { 2 - 12 } & EU 28 & 51.86 & 51.50 & 53.70 & 54.45 & 53.75 & 53.63 & 52.90 & 51.39 & 50.46 & 50.37 & 50.00 \\
\hline
\end{tabular}

Source: Statistica.com; ceicdata.com

\section{Tab. 3: The importance of motivational factors between 2008 and 2019}

\begin{tabular}{|c|c|c|}
\hline No. & Motivational factor & Arithmetic mean \\
\hline 1. & Basic salary & 4.43 \\
\hline 2. & The atmosphere at the workplace & 4.40 \\
\hline 3. & Good team & 4.38 \\
\hline 4. & Job assurance & 4.35 \\
\hline 5. & Fair employee assessment & 4.33 \\
\hline 6. & The supervisor's approach & 4.33 \\
\hline 7. & Financial incentives & 4.28 \\
\hline 8. & Communication at the workplace & 4.22 \\
\hline 9. & Working hours & 4.13 \\
\hline 10. & Work environment & 4.12 \\
\hline 11. & Job performance & 4.09 \\
\hline 12. & Social benefits & 4.06 \\
\hline 13. & Recognition & 4.06 \\
\hline 14. & Duties and type of work & 4.03 \\
\hline 15. & Stress (stress elimination at the workplace) & 4.02 \\
\hline 16. & Education and personal growth & 4.01 \\
\hline 17. & Leisure time & 4.01 \\
\hline 18. & Working procedures & 3.99 \\
\hline 19. & Opportunity to exercise abilities & 3.98 \\
\hline 20. & Independent decision making & 3.94 \\
\hline 21. & Self-actualization & 3.93 \\
\hline 22. & Feedback on individual performance & 3.92 \\
\hline 23. & Psychological burden & 3.92 \\
\hline 24. & Company reputation & 3.89 \\
\hline 25. & The company's attitude to the environment & 3.87 \\
\hline 26. & The vision of the company & 3.86 \\
\hline 27. & Competences & 3.82 \\
\hline 28. & The physical difficulty of work & 3.76 \\
\hline 29. & Development of the region & 3.74 \\
\hline 30. & Prestige & 3.67 \\
\hline
\end{tabular}


Work hypotheses were subsequently defined:

H1: We assume that there is a significant dependence between the macroeconomic indicators and the selected incentive factors.

H2: We assume that there is a significant dependence between the macroeconomic indicators examined with a 1-year time shift and the selected incentive factors in the current year.

The data obtained from the research were processed in the program Statistica. The confidence interval of $95 \%$ was used.

\section{Research Results}

Based on the history of macroeconomic indicators in Slovakia (Tab. 2) we can conclude that, on the one hand, the average annual wage is rising, but on the other hand household debt is close to $50 \%$ of GDP, despite state remedies.
In the next step, we examined the importance of individual motivational factors. The results are presented in Tab. 3 . The first 10 motivational factors are factors those employees considered most important during the years 2008-2019.

Based on the results achieved in Tab. 3, we can conclude, that the most important motivating factors are, in particular, financial (basic salary, fair assessment of the employee, financial incentives), relationship (workplace atmosphere, good team, supervisor's approach, communication at the workplace) and job (job security, working hours, working environment) motivational factors.

After most important motivational factors' identification, we can examine the dependence of motivational factors on macroeconomic indicators. The results achieved within the years 2008-2017 are presented in Tab. 4.

\begin{tabular}{|c|c|c|}
\hline $\begin{array}{l}\text { Correlation of motivational fa } \\
\text { in period } 2008-2017 \text { without }\end{array}$ & $\begin{array}{l}\text { rs and macroeconon } \\
\text { ne shift - Part } 1\end{array}$ & ators \\
\hline Motivational factor & Average annual wage & Household debt \\
\hline The atmosphere at the workplace & 0.582 & 0.635 \\
\hline Good team & 0.601 & 0.671 \\
\hline Financial incentives & 0.486 & 0.464 \\
\hline The physical difficulty of work & 0.469 & 0.450 \\
\hline Job assurance & 0.466 & 0.547 \\
\hline Communication at the workplace & 0.663 & 0.711 \\
\hline Company reputation & -0.125 & -0.148 \\
\hline Opportunity to exercise abilities & 0.458 & 0.455 \\
\hline Duties and type of work & 0.636 & 0.611 \\
\hline Feedback on individual performance & 0.366 & 0.355 \\
\hline Working hours & 0.689 & 0.666 \\
\hline Work environment & 0.677 & 0.635 \\
\hline Job performance & 0.541 & 0.551 \\
\hline Working procedures & 0.403 & 0.363 \\
\hline Competences & 0.275 & 0.236 \\
\hline Prestige & 0.499 & 0.487 \\
\hline The supervisor's approach & 0.713 & 0.710 \\
\hline Independent decision making & 0.280 & 0.326 \\
\hline Self-actualization & 0.483 & 0.465 \\
\hline Social benefits & 0.564 & 0.574 \\
\hline Fair employee assessment & 0.368 & 0.376 \\
\hline Stress (stress elimination at the workplace) & 0.545 & 0.559 \\
\hline
\end{tabular}




\section{Tab. 4: Correlation of motivational factors and macroeconomic indicators in period 2008-2017 without a time shift - Part 2}

\begin{tabular}{l|c|c}
\multicolumn{1}{c|}{ Motivational factor } & Average annual wage & Household debt \\
\hline Psychological burden & $\mathbf{0 . 7 9 5}$ & $\mathbf{0 . 8 0 8}$ \\
\hline The vision of the company & 0.172 & 0.191 \\
\hline Development of the region & 0.299 & 0.349 \\
\hline Education and personal growth & 0.276 & 0.289 \\
\hline The company's attitude to the environment & 0.526 & 0.531 \\
\hline Leisure time & 0.615 & 0.620 \\
\hline Recognition & 0.489 & 0.511 \\
\hline Basic salary & 0.475 & 0.540 \\
\hline
\end{tabular}

Source: own

Note: Statistically significant dependencies are highlighted in bold.

The results presented in Tab. 4 show that the dependence between the six motivational factors (communication at the workplace, duties and type of work, working hours, working environment, superior approach, psychological burden) and the average annual wage is confirmed. From the statistical evaluation of the achieved results, we can state that a high tightness was recorded for all examined factors. The results also show that the seven motivational factors (atmosphere at the workplace, good team, communication at the workplace, working hours, working environment, superior approach, psychological burden) depend on the macroeconomic indicator of household debt. In almost all examined cases, it was a high tightness except for the motivational factor psychological burden, where a very high tightness was recorded. Based on the achieved results, we can state that we confirm $\mathrm{H} 1$. We conclude that there is a significant dependence between selected macroeconomic indicators and selected motivational factors in the current year.

Sometimes macroeconomic indicators immediately affect the employee's behaviour. In some cases, macroeconomic indicators will only become apparent over time. The comparison of motivational factors and macroeconomic indicators valid in previous year was the subject of analysis related to $H 2$. We monitored dependencies from 2008-2018. We compared the motivational factors for the years 20082018 with the macroeconomic indicators for the years 2007-2017. For this reason, the scope of the statistical population has been increased to 11 . Tab. 5 presents the achieved results of the summary correlation.

After applying a time shift in motivational factors 1 year ahead, a larger number of statistically significant dependencies was recorded (Tab. 5). The average annual wage affects in total 13 motivational factors (workplace atmosphere, good team, financial incentives, physical difficulty of work, duties and type of work, working hours, working environment, superior approach, social benefits, stress elimination at the workplace, psychological burden, the company's attitude to the environment, leisure time). In all cases, high tightness was confirmed, except for the motivational factor psychological burden, where a very high tightness was confirmed. The macroeconomic indicator household debt affects in total 11 motivational factors (atmosphere at the workplace, good team, communication at the workplace, duties and type of work, working hours, working environment, superior approach, social benefits, psychological burden, the company's attitude to the environment, leisure time). As in previous cases, high tightness has now been confirmed, in addition to the motivational factor of psychological burden, in which a very high tightness has been confirmed. Based on the achieved results, we accept hypothesis $H 2$. We can state, that there is a significant dependence between selected macroeconomic indicators in the current year and selected motivating factors at time shift of 1 year.

The subject of further research will be the 10 most important motivating factors and their 


\section{Tab. 5: Correlation of motivational factors and macroeconomic indicators} in period 2008-2018 with a time shift of 1 year

\begin{tabular}{|c|c|c|}
\hline Motivational factor & Average annual wage & Household debt \\
\hline The atmosphere at the workplace & 0.717 & 0.615 \\
\hline Good team & 0.704 & 0.676 \\
\hline Financial incentives & 0.624 & 0.519 \\
\hline The physical difficulty of work & 0.635 & 0.533 \\
\hline Job assurance & 0.486 & 0.452 \\
\hline Communication at the workplace & 0.722 & 0.693 \\
\hline Company reputation & -0.097 & -0.254 \\
\hline Opportunity to exercise abilities & 0.485 & 0.382 \\
\hline Duties and type of work & 0.687 & 0.616 \\
\hline Feedback on individual performance & 0.494 & 0.386 \\
\hline Working hours & 0.748 & 0.697 \\
\hline Work environment & 0.705 & 0.651 \\
\hline Job performance & 0.564 & 0.489 \\
\hline Working procedures & 0.468 & 0.337 \\
\hline Competences & 0.344 & 0.245 \\
\hline Prestige & 0.543 & 0.448 \\
\hline The supervisor's approach & 0.758 & 0.740 \\
\hline Independent decision making & 0.460 & 0.376 \\
\hline Self-actualization & 0.568 & 0.496 \\
\hline Social benefits & 0.686 & 0.628 \\
\hline Fair employee assessment & 0.480 & 0.404 \\
\hline Stress (stress elimination at the workplace) & 0.631 & 0.598 \\
\hline Psychological burden & 0.818 & 0.828 \\
\hline The vision of the company & 0.234 & 0.112 \\
\hline Development of the region & 0.397 & 0.326 \\
\hline Education and personal growth & 0.372 & 0.254 \\
\hline The company's attitude to the environment & 0.704 & 0.657 \\
\hline Leisure time & 0.686 & 0.653 \\
\hline Recognition & 0.533 & 0.476 \\
\hline Basic salary & 0.569 & 0.550 \\
\hline
\end{tabular}

Note: Statistically significant dependencies are highlighted in bold.

dependence on macroeconomic indicators. Dependencies will be analysed after applying a shift of 1 year. This is taken into account in Tab. 6.

Based on the results presented in Tab. 6, scatter plots were created in the next step for those motivational factors for which a statistically significant dependence occurred. We were the first to examine the macroeconomic indicator average annual wage and its impact on the importance of motivational factors workplace atmosphere, good work team, further financial evaluation, communication in the workplace, working hours, working environment and the approach of a superior. The results obtained are presented in Tab. 7 and Fig. 1. 


\begin{tabular}{|c|c|c|}
\hline $\begin{array}{l}\text { Correlation between } \\
\text { macroeconomic ind }\end{array}$ & $\begin{array}{l}\text { important motivation } \\
\text { eriod 2008-2018 with }\end{array}$ & $\begin{array}{l}\text { tors and selected } \\
\text { shift of } 1 \text { year }\end{array}$ \\
\hline Motivational factor & Average annual wage & Household debt \\
\hline The atmosphere at the workplace & 0.717 & 0.615 \\
\hline Good team & 0.704 & 0.676 \\
\hline Financial incentives & 0.624 & 0.519 \\
\hline Job assurance & 0.486 & 0.452 \\
\hline Communication at the workplace & 0.722 & 0.693 \\
\hline Working hours & 0.748 & 0.697 \\
\hline Work environment & 0.705 & 0.651 \\
\hline The supervisor's approach & 0.758 & 0.740 \\
\hline Fair employee assessment & 0.480 & 0.404 \\
\hline Basic salary & 0.569 & 0.550 \\
\hline
\end{tabular}

\section{Tab. 7: Correlation of selected motivational factors and average annual wage}

\begin{tabular}{l|c|c|c|c|c|c|c|c|c}
\multicolumn{1}{c|}{$\begin{array}{c}\text { Motivational factor } \\
\text { statistical indicator }\end{array}$} & Average & St. dev. & $\mathbf{r}$ & $\mathbf{r}^{2}$ & $\mathbf{t}$ & $\mathbf{p}$ & $\mathbf{N}$ & Inercept & $\begin{array}{c}\text { Reg. } \\
\text { coeff. }\end{array}$ \\
\hline Average annual wage & $11,960.55$ & 692.44 & & & & & & & \\
\hline $\begin{array}{l}\text { The atmosphere at the } \\
\text { workplace }\end{array}$ & 4.39 & 0.12 & 0.72 & 0.51 & 3.09 & 0.013 & 11 & 2.85 & 0.0001 \\
\hline Good team & 4.38 & 0.12 & 0.70 & 0.50 & 2.97 & 0.016 & 11 & 2.90 & 0.0000 \\
\hline Financial incentives & 4.27 & 0.25 & 0.62 & 0.39 & 2.39 & 0.040 & 11 & 1.57 & 0.0002 \\
\hline $\begin{array}{l}\text { Communication at the } \\
\text { workplace }\end{array}$ & 4.21 & 0.13 & 0.72 & 0.52 & 3.13 & 0.012 & 11 & 2.56 & 0.0001 \\
\hline Working hours & 4.13 & 0.18 & 0.75 & 0.56 & 3.38 & 0.008 & 11 & 1.78 & 0.0002 \\
\hline Work environment & 4.11 & 0.16 & 0.71 & 0.50 & 2.99 & 0.015 & 11 & 2.11 & 0.0002 \\
\hline The supervisor's approach & 4.33 & 0.12 & 0.76 & 0.57 & 3.49 & 0.007 & 11 & 2.81 & 0.0001 \\
\hline
\end{tabular}

When analysing the dependence of the importance of motivational factors and the macroeconomic indicator of average annual salary, a statistically high direct dependence was recorded for the motivational factors of the atmosphere at the workplace $(r=0.72)$, good team $(r=0.70)$, communication at the workplace $(r=0.72)$, working hours $(r=0.75)$ working environment $(r=0.71)$ and the superior approach $(r=0.76)$. Significant dependence was confirmed in the analysis of the importance of motivational factor financial incentives $(r=0.62)$. Based on the results, we can state that with the growing average annual salary, the importance of the examined motivational factors grows. The degree of causal dependence of the motivational factors atmosphere at the workplace $\left(r^{2}=0.51\right)$, communication at the workplace $\left(r^{2}=0.52\right)$, working hours $\left(r^{2}=0.56\right)$ and approach of the superior $\left(r^{2}=0.57\right)$ are in high tightness. In the case of the motivational factor the atmosphere at the workplace, we can say that $51 \%$ of variability is caused by linear relationship with the variable of average annual wage. The remaining $49 \%$ variability can be explained by other reasons than the linear dependence of these two variables. The degree of causal dependence of the motivational 

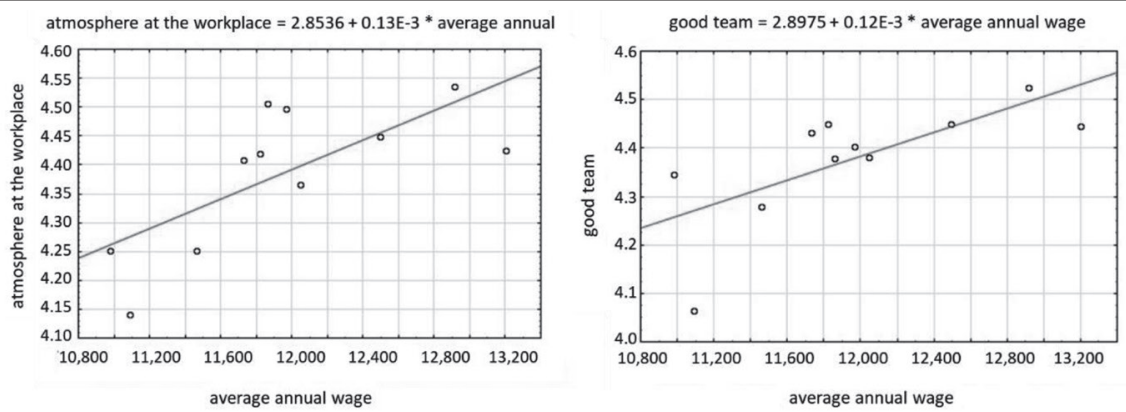

communication at the workplace $=2.5592+0.14 \mathrm{E}-3 *$ average annual
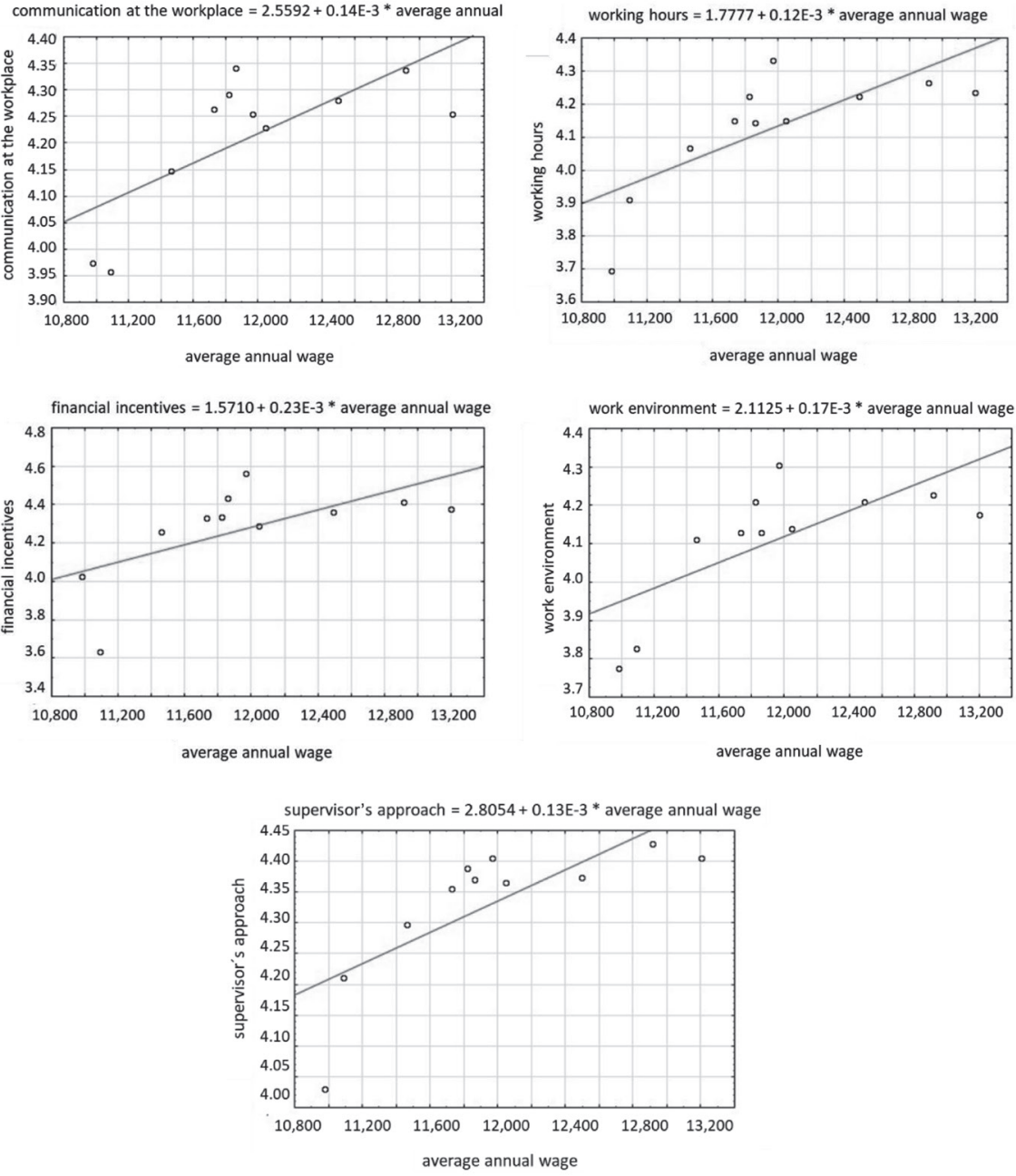


\section{Tab. 8: Correlation of selected motivational factors and household debt}

\begin{tabular}{l|c|c|c|c|c|c|c|c|c}
\multicolumn{1}{c|}{$\begin{array}{c}\text { Motivational factor } \\
\text { statistical indicator }\end{array}$} & Average & St. dev. & $\mathbf{r}$ & $\mathbf{r}^{2}$ & $\mathbf{t}$ & $\mathbf{p}$ & $\mathbf{N}$ & Inercept & $\begin{array}{c}\text { Reg. } \\
\text { coeff. }\end{array}$ \\
\hline Household debt & 31.84 & 6.59 & & & & & & & \\
\hline $\begin{array}{l}\text { The atmosphere at the } \\
\text { workplace }\end{array}$ & 4.39 & 0.12 & 0.61 & 0.38 & 2.34 & 0.044 & 11 & 4.02 & 0.01 \\
\hline Good team & 4.38 & 0.12 & 0.68 & 0.46 & 2.75 & 0.023 & 11 & 3.98 & 0.01 \\
\hline $\begin{array}{l}\text { Communication at the } \\
\text { workplace }\end{array}$ & 4.21 & 0.13 & 0.69 & 0.48 & 2.88 & 0.018 & 11 & 3.77 & 0.01 \\
\hline Working hours & 4.13 & 0.18 & 0.70 & 0.49 & 2.92 & 0.017 & 11 & 3.51 & 0.02 \\
\hline Work environment & 4.11 & 0.16 & 0.65 & 0.42 & 2.57 & 0.030 & 11 & 3.60 & 0.02 \\
\hline The supervisor's approach & 4.33 & 0.12 & 0.74 & 0.55 & 3.30 & 0.009 & 11 & 3.91 & 0.01 \\
\hline
\end{tabular}

factors good team $\left(r^{2}=0.50\right)$, financial benefits $\left(r^{2}=0.39\right)$ and working environment $\left(r^{2}=0.50\right)$ are in significant tightness. In the case of the motivational factor good team, we can say that $50 \%$ of variability is caused by linear relationship with the variable of average annual wage. The remaining $50 \%$ of variability can be explained by other reasons than the linear dependence of these two variables.

In the next step, household debt and its impact on motivational factor is the subject of analysis. According to the findings in Tab. 6, we have focused on the following motivational factors: the atmosphere at the workplace, good team, communication at the workplace, working hours, work environment and the supervisor's approach. The results obtained are presented in Tab. 8 and Fig. 2.

When analysing the dependence of the importance of motivational factors and the macroeconomic indicator of household debt, a statistically high direct dependence was recorded only for the motivational factor of the superior approach $(r=0.74)$. Significant dependence was confirmed in the analysis of the importance of motivational factors atmosphere at the workplace $(r=0.61)$, good team $(r=0.68)$, communication at the workplace $(r=0.69)$, working hours $(r=0.70)$, working environment $(r=0.65)$. Based on the results, we can state that with the growing household debt, the importance of the examined motivational factors grows. The degree of causal dependence of the motivational factor approach of the superior $\left(r^{2}=0.55\right)$ is in high tightness. Degree of causal dependence of motivational factors atmosphere at the workplace $\left(r^{2}=0.38\right)$, good work team $\left(r^{2}=0.46\right)$, communication at the workplace $\left(r^{2}=0.48\right)$, working hours $\left(r^{2}=0.49\right)$ and working environment $\left(r^{2}=0.42\right)$ is in significant tightness. In the case of the incentive factor of the superior approach, it follows from this that $55 \%$ of the variability of the superior approach variable can be explained by a linear relationship with the household debt variable. The remaining $45 \%$ variability of the parent access variable can be explained by other reasons than the linear dependence of these two variables.

\section{Discussion}

According to Němec et al. (2017), Kucharčíková and Mičiak (2018), Piotrowska (2019), Jung et al. (2020), and Pogodina et al. (2020), more than the capital strength and technological capabilities of a company, employees are a decisive factor in business success. These are considered to be the most important and most expensive source of production for a company, its main asset, which, if the company wants to exist, function, develop and continue at all, must be used with careful consideration to achieve set business goals (Kucharčíková et al., 2015; Stacho et al., 2017; Chulanova, 2019). The motivation of employees has become an essential part of the management of every company. Based on the knowledge that the quality of motivation of human potential fundamentally determines the quality of business operations, the motivation of individuals and groups has its positives and 


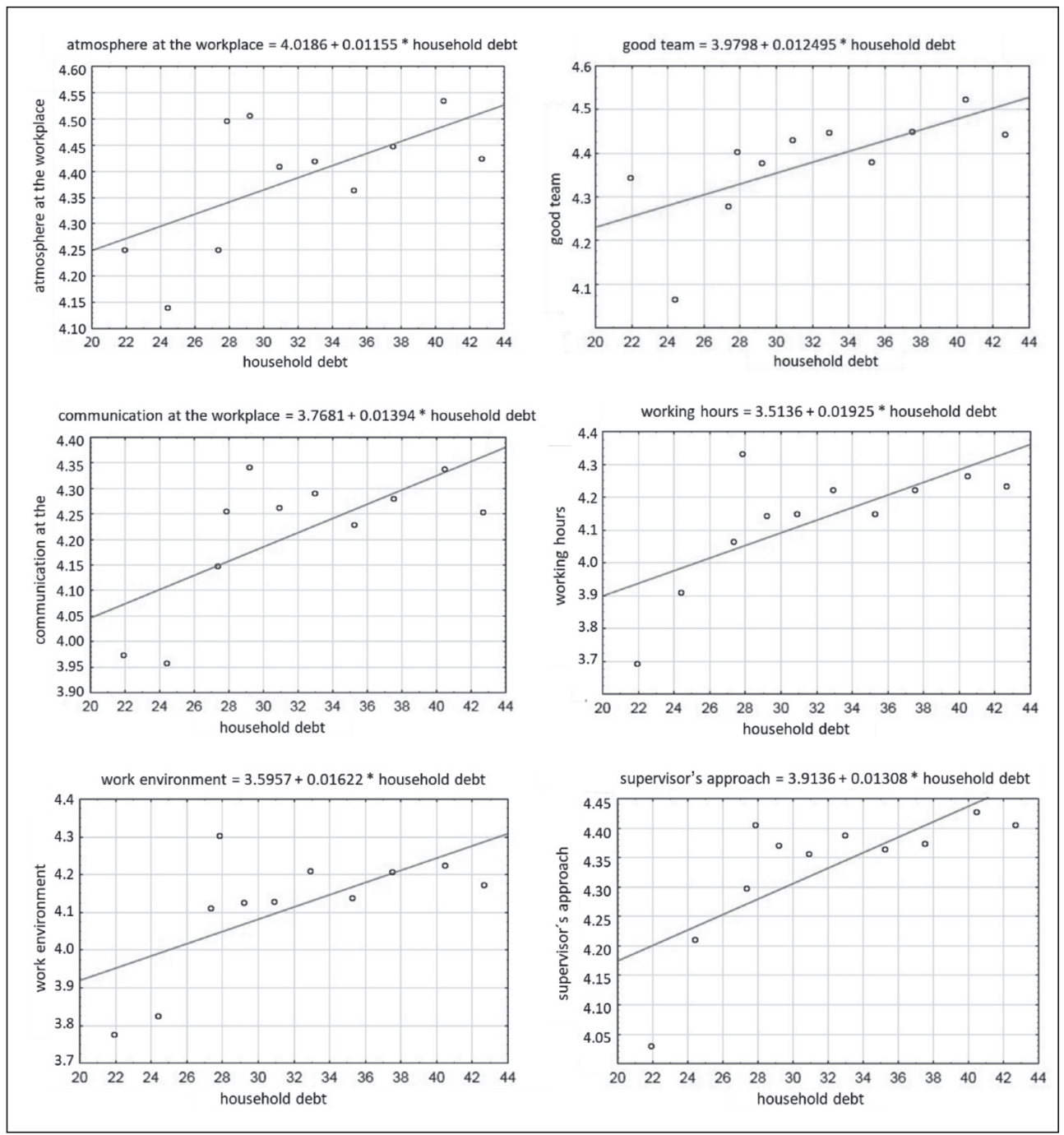

Source: own

limitations. The positives include the fact that individuals and groups with high motivation are able to work better, more efficiently, inventively, and more responsibly than individuals and groups with low motivation (Yang \& Jiang, 2010; Stacho \& Stasiak-Betlejewska, 2014). On the other hand, however high the motivation is, it is permanently confronted and weakened not only by internal factors (excessive stress, conflict, work and interpersonal failures) but also by external ones (economic, political, environmental, social, technological factors, economic crisis, macroenvironmental development) (Joniaková \& Blštákova, 2015; Stalmasekova et al., 2017; Bellé \& Cantarelli, 2018; Mahmoud et al., 2020; Ritala et al., 2020). This fact is the limitation. It is by combining all factors that are possible to create 
and strengthen the enthusiasm, enthusiasm, conviction and willingness of employees to engage in processes and activities that contribute to fulfilling the company's vision, mission and goals and at the same time the goals and aspirations of themselves.

An important starting point is a fact that a properly motivated employee works better than one who is not motivated. A motivated employee is willing to work, systematically, precisely, disciplined, with the full weight of responsibility and devote his energy, intellect and time to extremely demanding tasks when he sees that his work is appreciated. The key to success is truly motivating individuals and groups. Knowledge of what motivates employees enables managers to prepare conditions for continuous improvement and improvement of work performance. The manager must, therefore, know, use and strengthen the motivation of individuals, i.e. know what motivates employees and through appropriate approaches, motivational tools, positive communication, etc, motivation to address employees, match the motivation of individuals, groups and the whole company and purposefully develop and move it constantly. To a higher and higher quality level. The results of the research, which we carried out in the period from 2008 to 2019 , show that the most important motivating factors were employees' basic salary, the atmosphere in the workplace, good work team, job security, fair evaluation of the employee, superior approach, further financial evaluation, communication at work, working hours and working environment. The fact that the basic salary has long been the most important motivating factor is also confirmed by previous research (Wiley, 1997; Rynes et al., 2004; Casuneanu, 2011; Kropivšek et al., 2011; Pruneda, 2014). Motivational factors basic salary, fair evaluation of the employee and other financial evaluation were considered the most important financial motivational factors. Relational, motivational factors atmosphere in the workplace, a good work team, the approach of a superior and communication in the workplace were placed in the top ten most important factors. According to research, job security, working hours and the working environment were considered the most important work motivators. The same results are presented by Al Madi's (2017) research, which concluded that the most important motivating factors are considered to be financial and relational motivating factors. It is clear that various motivating factors have a great influence on the motivation of employees. For this reason, it is necessary to know currently right motivational factors, continuously monitor them and periodically evaluate in order to know the true state of the motivation of employees. It is mainly important to predict the further development of the creation of incentive programs.

A lot of research discovers the world of employee motivation. Even this paper makes a use of the secondary data for identification of relevant motivational factors from internal company environment. We did not identify any research focused on analysis of macroeconomic environment in relation with employee motivation. This paper is enriching the research in the field of motivation by analysis of relationship between macroeconomic factors (as a part of external company environment) and employee motivation. The results of the research show that we have confirmed a significant statistical dependence on the importance of motivational factors on macroeconomic indicators in the real year. At the same time, the research results confirmed a significant statistical dependence on the importance of motivational factors on macroeconomic indicators, even in a shift of one year. Correlation coefficients confirmed a statistically significant linear dependence in the shift of one year in the following cases:

- workplace atmosphere and reasonable annual wage $(r=0.72)$, household debt $(r=0.61)$;

- good staff and average annual wage $(r=0.70)$, household debt $(r=0.68)$;

- further financial evaluation and average annual salary $(r=0.62)$;

- workplace communication and average annual wage $(r=0.72)$, household debt $(r=0.69)$;

- working time and average annual wage $(r=0.75)$, household debt $(r=0.70)$;

- working environment and average annual wage $(r=0.71)$, household debt $(r=0.65)$;

- superior approach and average annual wage $(r=0.76)$, household debt $(r=0.74)$. As a result of a shift in the importance of motivational factors a year ahead of 
macroeconomic indicators, we found a higher incidence of dependencies. The results of the research further confirmed that the examined macroeconomic indicators influence the importance of motivational factors in direct linear dependence. Based on the achieved results, we can state that we confirmed both working hypotheses. Similar findings are presented by the research of Pavelka (2007) and Jureček (2013), who found that macroeconomic indicators reflect the course of the crisis. Similarly, Hitka and Vacek (2010) and Závadský et al. (2015) argue that motivation has changed since the economic crisis. Based on the achieved results, we believe that employees are affected not only by their income from work but also by their expenses when assessing the importance of motivational factors. The results further indicate that in some cases, there is scope to influence motivation with other variables along with macroeconomic indicators. Therefore, we recommend business managers to take into account not only the effects of the micro-environment on motivation but also the effects of the macro-environment and thus macroeconomic changes in the country when creating incentive programs. How managers should enter into the struggle for the motivation of the individual, the team and the company should be different, depending on the development of microeconomic and macroeconomic factors.

Further research of macroeconomic factors influence on motivation is needed. There are other macroeconomic indicators e.g. unemployment rate, social spending and others, with possible impact on employee motivation. Continuous research and analysis results cumulation will enrich the knowledge of factors affecting employee motivation in positive or negative way.

\section{Conclusions}

The 21st century is characterised by an immense pace of various changes, everincreasing demands and expectations. These dynamic features and requirements constantly affect employees and managers, undermine the strength/intensity of motivation, and even often weaken it. For this reason, it is necessary to constantly strengthen the motivation, improve, adapt, harmonise and orient in the right direction, to fulfil the vision and goals of the company. It is necessary to motivate individuals and groups and thus apply intentional motivation. If employees have the perspective and specific opportunities for professional development, functional progress and are evaluated for work in a way that corresponds to the quantity and quality of work performed, we can expect long-term and quality work performance from them. Important prerequisites for the long-term performance of employees, their willingness and satisfaction include the fact that employees perform work that is meaningful, important for the company, is interesting to them, to be reasonably demanding, fairly evaluated and provides opportunities for personal development. To maintain the required performance, it is necessary to continuously motivate the employee. Because motivation is influenced by various factors, it is necessary to continuously analyse the motivational needs of employees and, if necessary, update the content of the company's motivational programs. The incentive program is one of the tools for attracting employees, and in this area, companies should be creative enough to become interesting and attractive employers for current as well as future employees. Today's competition is not only regional but also demanding and increasingly transnational due to globalisation. The position of the company on the labour market must, therefore, be systemic in nature, must be complex and must be of a long-term nature.

Acknowledgement: This research was supported by projects KEGA 005TU Z-4/2020 "Economics, Management and Enterprising in Wood Industry Companies - university textbook with visualization support in virtual space", and VEGA 1/0161/21 "Dependence of the type of corporate culture on the industries of Slovak enterprises and selected socio-demographic factors".

\section{References}

Achim, I., Dragolea, L., \& Balan, G. (2013). The Importance of Employee Motivation to Increase Organizational Performance. Annales Universitatis Apulensis Series Oeconomica, 15(2), 685-691. https://doi.org/10.29302/ oeconomica.2013.15.2.32

Afsar, B., \& Umrani, W. A. (2020). Transformational Leadership and Innovative Work Behavior. The Role of Motivation to Learn, Task Complexity and Innovation Climate. European 
Journal of Innovation Management, 23(3), 402428. https://doi.org/10.1108/EJIM-12-2018-0257

Al Madi, F. (2017). The Impact of Employee Motivation on Organizational Commitment. European Journal of Business and Management, 19(15), 134-145.

Amabile, T. M., \& Kramer, S. J. (2010). What Really Motivates Workers. Harvard Business Review, 88(1), 44-45.

Anguelov, K., Stoyanova, T., \& Tamošiūnienè, R. (2020). Research of Motivation of Employees in the IT Sector in Bulgaria. Entrepreneurship and Sustainability Issues, 7(3), 2556-2567. https://doi.org/10.9770/jesi.2020.7.3(73)

Antov, P., Pancheva, T. V., \& Santas, P. (2017). Cooperative Learning Approach in Engineering Education. Science, Engineering \& Education, 2(1), 106-111.

Bajzikova, L., Novackova, D., \& Saxunova, D. (2017). Globalization in the case of automobile industry in Slovakia. In Proceedings of the 30th International Business Information Management Association Conference, IBIMA 2017 - Vision 2020: Sustainable Economic Development, Innovation Management, and Global Growth. Madrid, Spain.

Barreto, M. A. M., Vasconcelos, S. S., \& dos Santos, E. F. (2018). Motivation and Work: A Survey of the Motivational Aspects in Industries. In J. Kantola, T. Barath, \& S. Nazir (Eds.), Proceedings of the 8th International Conference on Applied Human Factors and Ergonomics. Los Angeles, CA, USA. https://doi. org/10.1007/978-3-319-60372-8_31

Bellé, N., \& Cantarelli, P. (2018). The Role of Motivation and Leadership in Public Employees' Job Preferences: Evidence from Two Discrete Choice Experiments. International Public Management Journal, 21(2), 191-212. https://doi.org/10.1080/10967494.2018.1425229

Bohorquez, E., Perez, M., Caiche, V., \& Rodriguez, A. B. (2020). Motivation and Work Performance: Human Capital as a Key Factor in an Organization. Revista Universidad $Y$ Sociedad, 12(3), 385-390.

Bowen, B. E., \& Radhakrishna, R. B. (1991). Job Satisfaction of Agricultural Education Faculty: A Constant Phenomena. Journal of Agricultural Education, 32(2), 16-22.

Bravena, N., \& Stara, J. (2018). The Themes of Global Development as a Challenge for Contemporary Education in the Reflection of Future Teachers. Communications - Scientific Letters of the University of Zilina, 20(1A), 101-108.
Casuneanu, C. (2011). The Romanian Employee Motivation System: An Empirical Analysis. International Journal of Mathematical Models and Methods in Applied Science, 5(5), 931-938.

Chatzopoulou, M., Vlachvei, A., \& Monovasilis, T. (2015). Employee's Motivation and Satisfaction in Light of Economic Recession: Evidence of Grevena Prefecture - Greece. Procedia Economics and Finance, 24, 136-145. https://doi.org/10.1016/S22125671(15)00633-4

Chulanova, Z. K. (2019). Professional Standards as a Factor of Adaptation of Human Resources to the Industry 4.0: Approaches to Development and Implementation. Journal of Human Resource Management, 22(1), 12-20.

Çinar, O., Bektas, C., \& Aslan, I. (2011). A Motivation Study on the Effectiveness of Intrinsic and Extrinsic Factors. Economics and Management, 16, 690-695.

Crewson, P. E. (1997). Public-Service Motivation: Building Empirical Evidence of Incidence and Effect. Journal of Public Administration Research and Theory, 7(4), 499-518. https://doi.org/10.1093/oxfordjournals. jpart.a024363

Dahake, P. S. (2018). Role of Fair Reward, Incentives and Remuneration System for Motivating Sales People of Banking, Financial Services and Insurance (BFSI) Sector. Helix, 8(6), 4241-4246. https://doi. org/10.29042/2018-4241-4246

Damij, N., Levnajić, Z., Skrt, V. R., \& Suklan, J. (2015). What Motivates Us for Work? Intricate Web of Factors beyond Money and Prestige. Plos One, 10(7), e0132641. https://doi.org/10.1371/journal.pone.0132641

Dick, S. D. (2019). Generational Similarities in Work Values of Generations X, Y and Z. Journal of Human Resource Management, 22(2), 10-27.

Fakhrutdinova, E., Kolesnikova, J., Yurieva, O., \& Kamasheva, A. (2013). The Commercialisation of Intangible Assets in the Information Society. World Applied Sciences Journal, 27, 82-86. https://doi.org/10.5829/ idosi.wasj.2013.27.emf.17

Faletar, J., Jelačić, D., Sedliačiková, M., Jazbec, A., \& Hajdúchová, I. (2016). Motivating Emploees in a Wood Processing Company before and after Restructuring. BioResources, 11(1), 2504-2515. https://doi.org/10.15376/ biores.11.1.2504-2515 
Fapohunda, T. M. (2017). Gender and Impression Management in the Workplace. Acta Oeconomica Universitatis Selye, 6(2), 47-56.

Hajdúchová, I., \& Hlaváčková, P. (2014). Impact of Global Economy of Forestry and Forest Based Industry in the Czech and Slovak Republic. Acta Facultatis Xylologiae Zvolen, 56(2), 135-146.

Halaj, D., Sedliačiková, M., \& Malá, D. (2018). Customer Behavior on the Slovakian Roundwood Market: A Case Study. BioResources, 13(3), 6003-6020. https://doi. org/10.15376/biores.13.3.6003-6020

Herzberg, F. (1968). Work and the Nature of Man. London: Staples Press.

Hitka, M. (2009). Model analýzy motivácie zamestnancov výrobných podnikov [Production companies'employee motivation model]. Zvolen: Technical University of Zvolen Publishing.

Hitka, M., Lipoldová, M., \& Schmidtová, J. (2020). Employees' Motivation Preferences in Forest and Wood-Processing Enterprises. Acta Facultatis Xylologiae Zvolen, 62(1), 151-164. https://doi.org/10.17423/afx.2020.62.1.13

Houston, D. J. (2000). Public - Service Motivation: A Multivariate Test. Journal of Public Administration Research and Theory, 10(4), 713-727. https://doi.org/10.1093/ oxfordjournals.jpart.a024288

llea, C. D. N., Daina, L. G., Bungau, S., Tit, D. M., Uivarosan, D., Moleriu, L., Petre, I., Bungau, C., \& Petre, I. (2020). Sustainable Management, Instable Legislation Regarding Wages, and Employee Satisfaction/Motivation in Two Romanian Hospitals. Sustainability, 12(3). https://doi.org/10.3390/su12030909

Jelačić, D., Šatanová, A., Sedliačiková, M., Zavadský, J., \& Zavadská, Z. (2015). Process Model of Quality Cost Monitoring for Small and Medium Wood-Processing Enterprises. Drvna Industrija, 66(4), 329-338. https://doi. org/10.5552/drind.2015.1437

Joniaková, Z., \& Blštáková, J. (2015). Age Management as Contemporary Challenge to Human Resources Management in Slovak Companies. Procedia Economics and Finance, 34, 202-209. https://doi.org/10.1016/S22125671(15)01620-2

Ju, C. J. (2020). Work Motivation of Safety Professionals: A Person-Centred Approach. Safety Science, 127, 104697. https://doi. org/10.1016/j.ssci.2020.104697
Jung, H. S., Seo, K. H., \& Yoon, H. H. (2020). The Importance of Leader Integrity on Family Restaurant Employees' Engagement and Organisational Citizenship Behaviors: Exploring Sustainability of Employees' Generational Differences. Sustainability, 12(6), 2504. https://doi.org/10.3390/su12062504

Jurečka, V., Hlaváček, K., Jánošíková, I., Kolcunová, E., Macháček, M., Paličková, I., Spáčilová, L., \& Wroblovský, T. (2013). Makroekonomie [Macroeconomics]. Prague: Grada Publishing.

Kalina, P. (2020). Change Management: COVID-19 and Beyond. Journal of Human Resource Management, 23(1), 38-40.

Karpichev, V., Sergeev, K., \& Bolotina, A. (2019). Modeling of Technological Processes of Machine-Building and Repair Manufacture. Communications - Scientific Letters of the University of Zilina, 21(4), 59-62. https://doi. org/10.26552/com.C.2019.4.59-62

Klopotan, I., Generalić, M., \& Mihevc, Z. (2018). Parameters which Influence Employee Satisfaction in Public Sector in the Republic of Croatia. International Journal for Quality Research, 12(2), 405-420. https://doi.org/10.18421/IJQR12.02-07

Kohnová, L., Papula, J., \& Salajová, N. (2019). Internal Factors Supporting Business and Technological Transformation in the Context of Industry 4.0. Business: Theory and Practice, 20, 137-245. https://doi.org/10.3846/ btp.2019.13

Koval'ová, M., Hvolková, L., Klement, L., \& Klementová, V. (2018). Innovation Strategies in the Slovak Enterprises. Acta Oeconomica Universitatis Selye, 7(1), 79-89.

Kropivšek, J., Jelačić, D., \& Grošelj, P. (2011). Motivating Employees of Slovenian and Croatian Wood-industry Companies in Times of Economic Downturn. Drvna Industrija, 62(2), 97-103. https://doi.org/10.5552/ drind.2011.1040

Kubal'a, J., \& Vetráková, M. (2018). Reasons of the Employees' Stabilization in Hotels in Slovakia. Acta Oeconomica Universitatis Selye, 6(2), 90-100.

Kucharčíková, A., \& Mičiak, M. (2018). Human Capital Management in Transport Enterprises with the Acceptance of Sustainable Development in the Slovak Republic. Sustainability, 10(7), $2530 . \quad$ https://doi. org/10.3390/su10072530 
Kucharčíková, A., Tokarčíková, E., \& Ďurišová, M. (2015). Human Capital Efficiency in Trading Company. In Proceeding of the 9th International Days of Statistics and Economics (pp. 892-901). Prague, Czech Republic.

Ližbetinová, L. (2017). Clusters of Czech Consumers with Focus on Domestic Brands. In Proceeding of the 29th International-BusinessInformation-Management-Association Conference (pp. 1703-1716). Vienna, Austria.

Loučanová, E., Olšiaková, M., \& Dzian, M. (2018). Suitability of innovative Marketing Communication Forms in the Furniture Industry. Acta Facultatis Xylologiae Zvolen, 60(1), 159171. https://doi.org/10.17423/afx.2018.60.1.17

Luthans, F. (1998). Organisational Behavior. New York, NY: McGraw-Hill Irwin.

Mahmoud, A. B., Reisel, W. D., Grigoriou, N., Fuxman, L., \& Mohr, I. (2020). The Reincarnation of Work Motivation: Millennials vs Older Generations. International Sociology, 35(4), 393-414. https://doi. org/10.1177/0268580920912970

Mészáros, M. (2018). Employing of SelfEmployed Persons. Central European Journal of Labour Law and Personnel Management, 1(1), 46-67. https://doi.org/10.33382/ cejllpm.2018.01.04

Moresová, M., Sedliačiková, M., Štefko, J., \& Benčiková, D. (2019). Perception of Wooden Houses in the Slovak Republic. Acta Facultatis Xylologiae Zvolen, 61(2), 121-135. https://doi. org/10.17423/Afx.2019.61.2.12

Myint, S. S., Leamprecha, N., Pooncharoen, N., \& Rurkwararuk, W. (2016). An Analysis of Employee Satisfaction of Private Banks in Myanmar. International Business Management, 10(2), 101-114.

Němec, M., Krišt’ák, L., Hockicko, P., Danihelová, Z., \& Velmovská, K. (2017) Application of Innovative P\&E Method at Technical Universities in Slovakia. EURASIA Journal of Mathematics Science and Technology Education, 13(6), 2329-2349. https://doi.org/10.12973/eurasia.2017.01228a

Neykov, N., Krištáková, S., Hajdúchová I., Sedliačiková, M., Antov, P., \& Giertliová, B. (2021). Economic Efficiency of Forest Enterprises - Empirical Study Based on Data Envelopment Analysis. Forests, 12(4), 462. https://doi.org/10.3390/f12040462

Olafsen, A. H., \& Bentzen, M. (2020). Benefits of Psychological Detachment from Work: Does Autonomous Work Motivation
Play a Role? Frontiers in Psychology, 11, 824. https://doi.org/10.3389/fpsyg.2020.00824

Pacáková, V., Labudová, V., Sipková, L'., Šoltéz, E., \& Vojtková, M. (2009). Štatistické metódy pre ekonómov [Statistical methods for economists]. Bratislava: Wolters Kluwer IURA Edition.

Paluš, H., Parobek, J., Dzian, M., ŠimoSvrček, S., \& Krahulcová, M. (2019). How Companies in the Wood Supply Chain Perceive the Forest Certification. Acta Facultatis Xylologiae Zvolen, 61(1), 155-165. https://doi. org/10.17423/afx.2019.61.1.15

Piotrowska, M. (2019). Facets of Competitiveness in Improving the Professional Skills. Journal of Competitiveness, 11(2), 95-112. https://doi.org/10.7441/joc.2019.02.07

Pogodina, T. V., Muzhzhavleva, T. V., \& Udaltsova, N. L. (2020). Strategic Management of the Competitiveness of Industrial Companies in an Unstable Economy. Entrepreneurship and Sustainability Issues, 7(3), 1555-1564. https:// doi.org/10.9770/jesi.2020.7.3(9)

Potkány, M., Debnár, M., \& Škultétyová, M. (2019). Life Cycle Cost Analysis for Reference Prototype Building in Alternatives of Silicate and Wood-Based Structure. Acta Facultatis Xylologiae Zvolen, 61(2), 137-152. https://doi. org/10.17423/afx.2019.61.2.13

Pruneda, G. (2014). Determinantes y Evolución de la Motivación de los Trabajadores en un Contexto de Crisis Económica. El caso de España. Papers. Revista de Sociologia. Universitat Autonoma de Barcelona, 99(1), 41-72. http://doi.org/10.5565/rev/papers/ v99n1.514

Rajhans, K. (2012). Effective Organisational Communication: A Key to Employee Motivation and Performance. Interscience Management Review, 2(2), 81-85.

Renard, M., \& Snelgar, R. J. (2018). Can Non-profit Employees' Internal Desires to Work Be Quantified? Validating the Intrinsic Work Motivation Scale. South African Journal of Psychology, 48(1), 48-60. https://doi. org/10.1177/0081246317704125

Ritala, P., Vanhala, M., \& Järveläinen, K. (2020). The Role of Employee Incentives and Motivation on Organisational Innovativeness in Different Organisational Cultures. International Journal of Innovation Management, 24(4), 2050075. https://doi.org/10.1142/ S1363919620500759 
Rožman, M., Tominc, P., \& Milfelner, B. (2020). A Comparative Study Using Two SEM Techniques on Different Samples Sizes for Determining Factors of Older Employee's Motivation and Satisfaction. Sustainability, 12(6), 2189. https://doi.org/10.3390/ su12062189

Rynes, S. L., Gerhart, B. Y., \& Minette, K. A. (2004). The Importance of Pay in Employee Motivation: Discrepancies Between What People Say and What They Do. Human Resource Management, 43(4), 381-394. https://doi.org/10.1002/hrm.20031

Sedliačiková, M., Stroková, Z., Drábek, J., \& Malá, D. (2019). Controlling Implementation: What Are the Benefits and Barries for Employees of Wood Processing Enterprises? Acta Facultatis Xylologiae Zvolen, 61(2), 163173. https://doi.org/10.17423/afx.2019.61.2.15

Sedliacikova, M., Vacek, V., \& Sopkova, E. (2015). How Slovak Small and Medium Enterprises Perceive Financial Controlling. Procedia Economics and Finance, 26, 82-85. https://doi.org/10.1016/S2212-5671(15)00842-4

Smith, G. P. (1994). Motivation. In W. Tracey (Ed.), Human resources management and development handbook (2nd ed.). 's-Hertogenbosch: AMACOM.

Srivastava, R. (2014). The Impact of Communication Skill of the Manager on the Motivation, and Work Performance of the Employees - A Research Study. Pacific Business Review International, 6(9), 31-36.

Stacho, Z., \& Stasiak-Betlejewska, R. (2014). Approach of Organisations Operating in Slovakia to Employee's Performance Evaluation. Economic Annals-XXI, 5-6, 82-85.

Stacho, Z., Stachova, K., \& Vicen, V. (2017). Education of Employees during Dismissal Process. In Proceedings of the 14th International Conference Efficiency and Responsibility in Education. Prague, Czech Republic.

Stacho, Z., Stachová, K., Hudáková, M., \& Stasiak-Betlejewska, R. (2017). Employee Adaptation as Key Activity in Human Resource Management upon Implementing and Maintaining Desired Organisational Culture. Serbian Journal of Management, 12(2), 305315. https://doi.org/10.5937/sjm12-10340

Stacho, Z., Stachová, K., Papula, I., Papulová, Z., \& Kohnová, L. (2019). Effective Communication in Organisations Increases Their Competitiveness. Polish Journal of
Management Studies, 19(1), 391-403. https://doi.org/10.17512/pjms.2019.19.1.30

Stachová, K., Stacho, Z., Blštákova, J., Hlatká, M., \& Kapustina, L. M. (2018). Motivation of Employees for Creativity as a Form of Support to Manage Innovation Processes In Transportation-Logistics Companies. Naše More, 65(4), 180-186. https://doi.org/10.17818/ NM/2018/4SI.3

Stachová, K., Stacho, Z., Cagáňová, D., \& Stareček, A. (2020). Use of Digital Technologies for Intensifying Knowledge Sharing. Applied Sciences, 10(12), 4281. https://doi.org/10.3390/ app10124281

Stalmasekova, N., Genzorova, T., \& Corejova, T. (2017). Employee Benefits as One of Factors of Work Motivation. In Proceedings of the Cbu International Conference: Innovations in Science and Education. Prague, Czech Republic.

Štarchoň, P., Weberová, D., \& Ližbetinová, L. (2017). Clustering Czech consumers according to their spontaneous awareness of foreign brands. In Proceedings of the 29th International Business Information Management Association Conference Education Excellence and Innovation Management through Vision 2020: From Regional Development Sustainability to Global Economic Growth.

Strakova, J., Kucharcikova, A., Partlova, P., \& Vachal, J. (2016). Foreign Direct Investment and Transport Serviceability - A Prerequisite for the Development and Stability of National and Regional Economies. Naše More, 63(3), 204210. https://doi.org/10.17818/NM/2016/SI24

Weberová, D., \& Ližbetinová, L. (2016). Consumer attitudes towards brands in relation to price. In Proceedings of the 27th International Business Information Management Association Conference Innovation Management and Education Excellence Vision 2020 from Regional Development Sustainability to Global Economic Growth. Milan, Italy.

Wiley, C. (1997). What Motivates Employees According to Over 40 Years of Motivational Surveys. International Journal of Manpower, 18(3), 263-280. https://doi. org/10.1108/01437729710169373

Yang, J., \& Jiang, Y. (2010) Analysis of Achievement Motivation of College Student. Peking University Education Review, 8(1), 63-69.

Zaborova, E., \& Markova, T. (2018). Human Capital as a Factor of Regional Development. In Proceedings of the 12th International Days 


\section{Economics}

of Statistics and Economics. Prague, Czech Republic.

Závadský, J., Hitka, M., \& Potkány, M. (2015). Changes of Employee Motivation of Slovak Enterprises Due to Global Economic Crisis. E\&M Economics and Management, 18(1), 57-66. https://doi.org/10.15240/ tul/001/2015-1-005
Zumbo, B. D., Gadermann, A. M., \& Zeisser, C. (2007). Ordinal Versions of Coefficients Alpha and Theta for Likert Rating Scales. Journal of Modern Applied Statistical Methods, 6(1), 21-29. https://doi.org/10.22237/ jmasm/1177992180 